\title{
Chapter 10 \\ Mapping the Maritime Occupational \\ Health and Safety Challenges Faced \\ by Canadian Seafarers
}

\author{
Desai Shan
}

\begin{abstract}
This chapter explores the occupational health and safety challenges faced by Canadian seafarers. Maritime occupations continue to be among the most dangerous occupations in the world. Technological development and climate change, as well as the increasing level of Arctic shipping opening driven by oceanographic changes together with technological innovation, lead to significant health and safety challenges for mariners in Canada. Drawing on findings from two research projects on seafaring occupational health and safety (OHS), including qualitative semistructured interviews with 25 Canadian seafarers and a preliminary legal review of Canadian maritime OHS law, this chapter presents some common OHS challenges confronted by Canadian seafarers and the gaps existing in the current Canadian maritime OHS law. These challenges include increasing Arctic shipping activities led by the climate change, intensified work-related mobility, and insufficient legal protection.
\end{abstract}

Keywords Canada $\cdot$ Occupational health and safety $\cdot$ Seafarers

\subsection{Introduction}

Maritime occupational health and safety (OHS) has attracted increasing research attention in recent years, but most studies focus on the OHS of international seafarers (Roberts et al. 2014; Sampson et al. 2017; Walters and Bailey 2013). Maritime OHS challenges faced by Canadian seafarers are underexamined in the current peerreviewed academic literature, particularly in coastal and inland shipping. To fill this

\footnotetext{
D. Shan $(\bowtie)$

Marine \& Environmental Law Institute, Schulich Law School, Dalhousie University, Halifax, Canada

Division of Community Health and Humanities, Faculty of Medicine, Memorial University of Newfoundland, St John's, NL, Canada

e-mail: desai.shan@dal.ca
} 
research gap, this chapter draws on and extends recently published findings from a study of Canadian seafarers working on the Great Lakes and St. Lawrence Seaway (Shan and Lippel 2019; Shan and Neis 2019), and from a legal analysis of current international and Canadian occupational health and safety law to explore the health and safety challenges in the context of Canadian short-sea shipping and Arctic shipping. The related studies were conducted between 2017 and 2018.

Maritime occupations continue to be associated with a high risk for injuries and fatalities. According to Lefkowitz (2013), the injury rate of global shipping was estimated at 850 per 100,000 seafarers. A transnational study found that $8.5 \%$ of seafarers suffered an injury during their most recent tour of duty (Jensen et al. 2004), and a Danish study found that the fatal accident rate in merchant shipping is ten times that in shore-based industries (Hansen et al. 2002). The fatal accident rate among seafarers in the United Kingdom was 14.5 per 100,000 workers between 2003 and 2012, which was 21 times that in the general British workforce and 4.7 times that in the construction industry (Roberts et al. 2014). The fatal accident rate in Canada among seafarers was 22 per 100,000 workers between 1996 and 2005, which was higher compared to the United Kingdom (Roberts et al. 2014). In Canada, taking the seafarers (tug, barge and other water transport) in the water transport industry in British Columbia as an example, the injury rate is about 400 per 100,000 seafarers, which is about half compared to the global rate (WorkSafe BC 2019). However, considering the provincial average injury rate is 200 per 100,000 workers, seafarers' injury rate is still high relative to the primarily land-based workforce in British Columbia (WorkSafe BC 2019).

The relative higher workplace injury and fatality rate at sea can be attributed to various occupational hazards. The occupational hazards faced by maritime workers can be divided into two types: occupational accident and occupational disease, including both physical and mental health. Occupational accidents can be divided into three categories: firstly, accidents related to maritime disaster, for example, accidents or incidents involving ships, such as collision, foundering and explosion; secondly, on-duty accidents, namely, personal accidents involving seafarers on duty, such as a fracture caused by snapping mooring lines; and thirdly, off-duty accidents, such as injuries caused by slips, trips and falls when seafarers are off duty on board (Roberts et al. 2014).

\subsection{Canadian Maritime Sector and Occupational Hazards at Sea}

Canada has the world's longest coastline at 243,042 km (Statistics Canada 2016). As a maritime nation, Canada's economy, culture and security have been closely connected with merchant shipping (CCA 2017). The 2018 Review of Maritime Transport shows that Canada has the world's 31st largest fleet with 220 Canadian flagged vessels and 149 vessels registered overseas (UNCTAD 2019). Canada has approximately 14,680 registered seafarers (Roussel 2018). Canadian export and import trades heavily rely upon foreign-flagged vessels for non-U.S. marine trade, 
but Canadian-flagged vessels carry about $98 \%$ of domestic tonnage, as well as trade between Canada and the United States (Minister of Transport 2015). This is mainly because of the cabotage protection contained in the Coasting Trade Act (1992). With this cabotage protection, in principle, only Canadian-flagged vessels are allowed to operate transport between Canadian ports (Coasting Trade Act 1992, s. 3.1). In addition, only Canadian citizens and permanent residents can serve on these ships. These vessels are also active in the Canada-United States marine trade, which was valued at \$216 billion over the 2006-2015 period (Statistics Canada 2015; Transport Canada 2015). Foreign vessels, only with a special license issued by Transport Canada, can carry domestic tonnage, which are of a very small proportion.

Domestic marine shipping activities are concentrated in four areas of the country: British Columbia, the Great Lakes and St. Lawrence Seaway, Atlantic Canada, and northern Canada (CCA 2016; Transport Canada 2015). From 2004 to 2011, the Pacific region accounted for $54 \%$ of all commercial vessel movements in Canada, followed by the Great Lakes and the St. Lawrence Seaway (29\%), Atlantic Canada (16\%), and northern Canada (1\%) (CCA 2016).

In British Columbia, Vancouver is the largest port for domestic marine trade, comprising mainly agriculture and food products, forest products and minerals, such as wheat, canola, limestone, stone and sand. In the Great Lakes and St. Lawrence Seaway, iron ore, fuel oils and wheat constituted the majority of marine transport. In Atlantic Canada, crude oil was the major commodity transported between the ports of Saint John, Come by Chance, and the Newfoundland offshore in 2011 (Statistics Canada 2012). Domestic marine trade in northern Canada includes the transport of most of the food, fuel, construction materials and other goods used in the North. These are essential supplies for Arctic communities (CCA 2017).

Canada's marine environment, and its domestic shipping design, patterns and activities, are very diverse; and the occupational hazards faced by seafarers are therefore also varied. According to an analysis conducted by the Council of Canadian Academies (2016), northern Canada has the highest rate of maritime accidents and incidents, including both ship accidents and accidents on board vessels, with 10.26 per 1000 vessel movements (Table 10.1). Shipping in northern Canada is

Table 10.1 Incident and accident rates based on vessel movements for different regions in Canada (2004-2011) (adapted from CCA 2016)

\begin{tabular}{l|l|l|l}
\hline & $\begin{array}{l}\text { Total number of vessel } \\
\text { movements } \\
(2004-2011)\end{array}$ & $\begin{array}{l}\text { Total number of } \\
\text { incidents and accidents } \\
(2004-2011)\end{array}$ & $\begin{array}{l}\text { Incidents and accidents } \\
\text { per 1000 vessel } \\
\text { movements }\end{array}$ \\
\hline Northern Canada & 3607 & 37 & 10.26 \\
\hline Atlantic Canada & 114,543 & 174 & 1.52 \\
\hline $\begin{array}{l}\text { Great Lakes and } \\
\begin{array}{l}\text { St. Lawrence } \\
\text { Seaway }\end{array}\end{array}$ & 206,235 & 1055 & 5.12 \\
\hline British Columbia & 380,472 & & 1.19 \\
\hline
\end{tabular}


subject to severe weather and ice conditions. In addition, the lack of port and terminal infrastructure increases the risk of accidents and incidents. The Great Lakes and St. Lawrence Seaway have the second highest rate of incidents and accidents. This reflects the abundance of narrow waterways, canals and locks, which increase the risk of grounding, allision and collision. British Columbia and Atlantic Canada have significantly lower rates of incidents and accidents compared to northern Canada and the Great Lakes and St. Lawrence Seaway.

As pointed by Roberts et al. (2014), maritime accidents contribute 5\% of the fatalities of seafarers in the United Kingdom, while occupational accidents and offduty accidents on board are the cause of $70 \%$ of the fatalities of seafarers. Suicide and undetermined intent (including alcohol, drug intoxication, drowning and missing at sea) contribute $25 \%$ of the fatalities of seafarers. Occupational hazards related to general shipping labour processes include watchkeeping during the voyage, piloting through narrow waterways, mooring and anchoring at terminals, loading and discharging cargo, cargo handling, and trimming, marine engineering, and vesselsourced pollutant processing (Larson 1997; Walters and Bailey 2013). Canadian seafarers confront additional risks related to landing boom operations, that is, operation of a boom to swing crew members ashore to handle mooring lines on tie-up walls (The St. Lawrence Seaway Management Corporation 2019). This practice is unique to the Seaway. Frequent calls to ports in the near coastal regions will also require seafarers to be on call and shorten their rest hours (Pauksztat 2017). Shortsea seafarers are more vulnerable to fatigue compared to deep sea seafarers, which is a recently recognized workplace hazard (Shan and Neis 2019). The remainder of this chapter will explore three aspects of the OHS challenges faced by Canadian seafarers: challenges caused the climate change, in particular, the increase of Arctic shipping activities; challenges related to commuting and intensive work-related mobility; and challenges arising from insufficient OHS rights.

\subsection{Methods}

This chapter draws on findings from two research projects: (1) On the Move: Occupational Health and Safety Regulations and Management on Canadian Vessels on the Great Lakes and St. Lawrence Seaway (2017-2018); and (2) Regulating Maritime Occupational Health and Safety in the Canadian Arctic Gateway (2018-2020). The first project adopted qualitative research methods, which are recognized as valuable instruments to obtain insights into the experiences and views of stakeholders (Silverman 2011), including 25 semi-structured in-depth interviews with seafarers with working experiences on the Great Lakes and St. Lawrence Seaway, safety managers, human resource managers, representatives from unions and charities, and key informants from Canadian maritime authorities. The research was approved by the University of Ottawa Research Ethics Board. The research methods also included legal doctrinal analysis, documentary analysis drawing on legal sources, to provide a technically accurate portrait of the applicable regulatory 
framework (Lippel et al. 2016). The author conducted legal research using both international conventions and Canadian acts and regulations collected from the official websites of the International Maritime Organization (http://www.imo.org/en/ KnowledgeCentre/Pages/Default.aspx) and Transport Canada (https://www.tc.gc. ca/eng/acts-regulations/menu.htm). "Health", "safety" and "seafarers" are used as keywords in the legal research. A selection of collective bargaining agreements provided by the interviewees was also analysed to understand contractual rules applicable to the working conditions of Canadian seafarers on the Great Lakes and St. Lawrence Seaway. The second project is an on-going research project, and the findings reported in this chapter are mainly from legal analysis results. Similar to the first research project, in the second project, the author is collecting and analysing both international conventions and Canadian acts and regulations related to Arctic shipping from the official websites mentioned above.

Between them, the two projects cover two of the main maritime regions in Canada, the Great Lakes and St. Lawrence Seaway, and northern Canada, including those with the highest accident/incident rates. This chapter examines the challenges faced by Canadian maritime workers from the perspective of empirical accounts of seafarers, as well as conducting legal analysis of current maritime regulations. In addition, the gaps existing in Canadian maritime OHS law are discussed.

\subsection{Occupational Health and Safety Challenges Faced by Canadian Seafarers}

Occupational health and safety challenges include both risk factors related to weather, environment and marine operations, and those related to institutional and regulatory factors. This section presents study findings related to OHS risk factors faced by Canadian seafarers related to climate change, work-related mobility and insufficient legal protection.

\subsubsection{Climate Change}

Maritime activities in Canada have been affected by climate change, in particular the opening of the Arctic. The increasing loss of sea ice in the Arctic is expected to result in significant growth of various forms of maritime activities in this region. In 2014, Arctic shipping comprised 9.3\% of the world's shipping traffic (Eguíluz et al. 2016). The Arctic has been used as a transit route between the Pacific and the Atlantic for the international shipping industry, in particular the Northern Sea Route (NSR) on Russia's side of the Arctic between North Cape and the Bering Strait. Compared to traditional route sailing through the Panama or Suez Canals, it has been suggested that the NSR offers a $40 \%$ shortcut in terms of distance (Lasserre and Faury 2020). The Northwest Passage (NWP) is a sea corridor through Canada's 
Table 10.2 Number of voyages in the Canadian Arctic (adapted from Laserre 2019)

\begin{tabular}{l|l|l|l|l|l|l|l}
\hline & 2005 & 2007 & 2009 & 2011 & 2013 & 2015 & 2017 \\
\hline Total number of ship voyages & 121 & 181 & 185 & 317 & 349 & 315 & 416 \\
\hline Cargo ships or barges & 65 & 101 & 100 & 126 & 127 & 120 & 188 \\
\hline Fishing vessels & 20 & 39 & 44 & 136 & 137 & 129 & 138 \\
\hline
\end{tabular}

Arctic Archipelago and along the northern coast of North America. It has remained little utilized for international traffic, mainly because of complicated natural conditions and environmental concerns (Lasserre and Faury 2020).

However, there has been an increase in destinational shipping connected to Arctic communities and resource extraction in the Canadian Arctic (Lasserre and Faury 2020). The number of voyages in the Canadian Arctic almost tripled between 2005 and 2017 (Table 10.2). On the one hand, the increased number of ship voyages (Table 10.2) in the Arctic creates new commercial and job opportunities for the Canadian shipping industry. On the other hand, it will also place Canadian seafarers in an extreme, remote, low-temperature and risky working environment. Extratropical cyclone weather conditions are identified as a major risk factor in the maritime working environment at sea (Rezaee et al. 2016).

The growth of Arctic shipping activities brings an increasing number of seafarers to the polar navigation environment, which has extraordinary risks that affect both maritime safety and occupational health. Adopted by the International Maritime Organization (IMO) in 2014, the International Code for Ships Operating in Polar Waters (Polar Code 2014/2015) identifies ten sources of hazards for polar maritime activities. Section 3.1 of the Polar Code identifies eight hazards that are directly related to health and safety of seafarers:

1. Ice, which may affect hull structure, stability, machinery systems, navigation, the outdoor working environment, maintenance and emergency preparedness tasks and malfunction of safety equipment and systems

2. Topside icing, with potential reduction of stability and equipment functionality

3. Low temperature, as it affects the working environment and human performance, maintenance and emergency preparedness tasks, material properties and equipment efficiency, survival time and performance of safety equipment and systems

4. Extended periods of darkness or daylight as it may affect navigation and human performance

5. Remoteness and possible lack of accurate and complete hydrographic data and information, reduced availability of navigational aids and seamarks with increased potential or groundings compounded by remoteness, limited search and rescue facilities, communication capability, and delays in emergency in emergency response

6. Potential lack of ship crew experience in polar operations, with potential for human error

7. Potential lack of suitable emergency response equipment

8. Rapidly changing and severe weather conditions, with the potential for escalation of incidents 
In the Northwest Passage, as mentioned above, destinational shipping plays a major role, a significant portion of which consists of domestic shipping activities carried out by Canadian ships and considered as cabotage. In principle, these vessels should be crewed by Canadian citizens and permanent residents. Increasing maritime activity in the Arctic means a growing number of Canadian maritime workers face the occupational hazards of the polar marine environment.

Additionally, noise caused by ice breaking operations affects the quality of sleep and worsens the fatigue experienced by seafarers (Sillitoe et al. 2010). Ship motion and noise are also challenging for seafarers to cope with at sea. Fierce swells in storms, machine noise on board, as well as ice-breaking noise seriously affect the sleep quality and patterns of seafarers on board a vessel. The motion of ships also increases the risk of slips, trips and falls for seafarers.

A finding of this research is that the lack of port infrastructure in the Arctic region is reported to make discharge operations more difficult and may create additional occupational hazards related to port operations. In the Canadian Arctic, except at the port of Churchill, seafarers have to conduct discharge operations without support from a port terminal. The lack of nautical charts also increases the unpredictability of Arctic navigation and increases the risk of maritime incidents, such as groundings. Working in the Arctic in a low-temperature environment may also create additional risks for individual seafarers, including numbness, frostbite and hypothermia (Mäkinen and Hassi 2009). Long-term working in the cold may also cause musculoskeletal disorders (Pienimäki 2002). Cooling also worsens the symptoms of many diseases, including respiratory and heart diseases (Pienimäki 2002).

\subsubsection{Commuting and Intensive Work-Related Mobility}

In addition to the challenges brought by the increase of Arctic shipping activities, long commuting and employment-related geographical mobility also impact Canadian seafarers' occupational health conditions. However, limited attention has been paid to Canadian maritime transport workers, although the excessive and complex work-related mobilities within seafaring jobs are well-recognized (Borovnik 2004). Taking Canadian seafarers working on the Great Lakes and St. Lawrence Seaway as an example, the work-related mobility includes both commuting from the east Pacific and west Atlantic coasts to the ports, and the intensive mobility on the waterway, which stretches 3700 kilometres from Duluth (United States) to the Atlantic Ocean. According to empirical studies conducted in 2017 and 2018 (Shan and Lippel 2019; Shan and Neis 2019), a commute of more than $5 \mathrm{~h}$ is common among Canadian seafarers working on the Great Lakes and St. Lawrence Seaway. In addition, every 6-12 weeks, many seafarers are placed directly on shifts after overnight commuting, which increases the risks associated with fatigue. Due to the complex system of canals and locks on the Great Lakes and St. Lawrence Seaway, some Canadian seafarers report that they have to work $12 \mathrm{~h}$, in particular on the Welland Canal, continuously after a 6-8 h commute (Shan and Neis 2019). As a 
result, they have no chance to take a proper sleep break within 18-20 h. Fatigue risk arising from long commutes also creates challenges for safety management on board the vessel. It is challenging for captains to supervise exhausted crew, because tired crew are not able to conduct safety-critical tasks on board (Shan and Neis 2019).

The Seaway system is connected by five canals, which include 15 locks. This means that seafarers must confront the challenges of navigating into and out of these canals and locks. To pass the locks safely, intensive manoeuvring of the vessel is required, and mooring may also be required during transit through the locks. Of the five canals on the Seaway system, navigating the Welland Canal with eight locks is reported to be the most fatiguing part of this system. Irregular working hours may break the circadian rhythm of seafarers, even though many human resource managers and captains try their best to maintain the minimum hours of rest required by law. In addition, the reduction of crew size increases the difficulty for Canadian seafarers to address intensive mobility, in particular the time-consuming vertical mobility across the locks and canals on the Great Lakes and St Lawrence Seaway (Shan and Neis 2019).

Seafarers work intensive shifts while navigating the locks including extended working hours and reduced and broken rest hours. Furthermore, quick turnarounds at the port mean seafarers may have to travel back down through the Welland Canal or the Montreal to Lake Ontario system again fairly soon afterwards. In our empirical study, one captain highlighted ways this work pattern, combined with a reduction in crew size (from 30 to 17 on some ships, and from 24 to 12 on other ships), contribute to fatigue on the downbound and upbound voyages. The only time to have some rest is during the 5-h sail on Lake Ontario (Shan and Neis 2019).

Intensive mobility, in particular the increasing competition in loading and discharging operations, restricts shore leave opportunities for seafarers. Some seafarers may not get ashore even once for the whole sailing season on the Great Lakes and St Lawrence Seaway. Seafarers' shore leave may create "unnecessary delay" in the highly competitive transport market (Shan and Neis 2019).

\subsubsection{Insufficient Occupational Health and Safety Rights}

Legal instruments that enshrine occupational health and safety rights are the primary tool used to protect seafarers from occupational hazards. Canadian seafarers' occupational health and safety rights are provided for under international conventions, including the Maritime Labour Convention, 2006 (MLC 2006), and Canadian domestic laws, including Canada Labour Code, Part II, Maritime Occupational Health and Safety Regulations, Canada Shipping Act, 2001, and Marine Personnel Regulations (MPR). Canada ratified the Maritime Labour Convention, 2006 in 2010, but implementation and enforcement of the standards takes time, and gaps between Canadian law and the Maritime Labour Convention, 2006 still can be identified. For example, under Section 319 of the MPR and Regulation 2.3 of the MLC 2006 concerning hours of work and rest, Canadian standards are lower compared to 
the international ones (International Labour Organization 2018). In addition, ships that navigate exclusively in inland waters or waters within, or closely adjacent to, sheltered waters are not subject to the provisions of the MLC 2006 (Article II.1 (i)). With respect to ships of less than 200 gross tonnage not engaged in international voyages, competent authorities, in consultation with the shipowners' and seafarers' organizations concerned, can determine the Codes of the MLC 2006 that are not applicable (Article II.6). Canadian seafarers are mainly involved in domestic shipping, and many work on ships that are not subject to the MLC 2006. For these seafarers, the Canada Labour Code and Canada Shipping Act, 2001 are the primary legal sources of their occupational health and safety rights, which have not been amended to an equivalent level to the international maritime labour standards.

To address the occupational health and safety hazards faced by seafarers, it is necessary to ensure there is sufficient protection of occupational health and safety rights in the regulatory framework. However, a legal analysis of Canadian maritime health and safety regulations identifies several gaps in maritime labour protection. These gaps pose challenges for seafarers because the weaker legal protection makes it more difficult for workers to voice their safety concerns and to participate in the control of the occupational hazards they face.

Canadian occupational health and safety law has adopted the internal responsibility system, which means although the employer has primary responsibility, all workplace stakeholders, including supervisors and workers, have statutory duties to ensure compliance. In the maritime industry, due to the total institutional nature of the ship as a working environment, many seafarers' occupational health and safety rights are restricted in order to adapt to the nature of the competitive transport market (Shan and Lippel 2019). The current protection of Canadian seafarers is relatively lower compared to land-based workers, and in some cases, there are gaps between Canadian maritime occupational health and safety standards and international ones.

The first gap is related to maximum working hours and minimum hours of rest. Canadian seafarers are exempted from the maximum hours of work stipulated in Section 171 of the Canada Labour Code, which are 48 h/week, under the East Coast and Great Lakes Shipping Employees Hours of Work Regulations (s. 5) and the West Coast Shipping Employees Hours of Work Regulations (s. 3). Instead, the MPR stipulate the minimum hours of rest for crew on federally regulated ships. There are two patterns of working hours adopted on Canadian ships, one is $4 \mathrm{~h}$ on $8 \mathrm{~h}$ off, and the other is $6 \mathrm{~h}$ on $6 \mathrm{~h}$ off. In both patterns, seafarers are required to take two work shifts of 4 or $6 \mathrm{~h}$ in $24 \mathrm{~h}$ (Shan and Neis 2019). When working on board, seafarers are required to work 7 days a week, which means regularly working between $56 \mathrm{~h}$ and $84 \mathrm{~h}$ per week. Working hours on board are much higher compared to land-based work, which is also a common practice in the international shipping industry (Sampson 2013).

Under Section 320 of the MPR, for Canadian vessels engaged on sheltered water voyages or near coastal voyages or vessels that are in any waters other than those of a foreign state that has ratified the MLC 2006, the master and the crew have (i) at least six consecutive hours of rest in every 24 -h period, and (ii) at least $16 \mathrm{~h}$ of rest 
Table 10.3 Application of minimum hours of rest standards

\begin{tabular}{|c|c|c|c|c|c|}
\hline & $\begin{array}{l}\text { Canadian } \\
\text { vessels } \\
\text { engaged on } \\
\text { sheltered } \\
\text { water } \\
\text { voyages }\end{array}$ & $\begin{array}{l}\text { Canadian vessels } \\
\text { engaged on near } \\
\text { coastal voyages in } \\
\text { any waters other } \\
\text { than those of a } \\
\text { foreign state that } \\
\text { has ratified MLC } \\
2006\end{array}$ & $\begin{array}{l}\text { Canadian vessels } \\
\text { engaged on near } \\
\text { coastal voyages } \\
\text { in waters of a } \\
\text { foreign state that } \\
\text { has ratified MLC } \\
2006\end{array}$ & $\begin{array}{l}\text { Canadian } \\
\text { vessels } \\
\text { engaged on } \\
\text { unlimited } \\
\text { voyages } \\
\end{array}$ & $\begin{array}{l}\text { Foreign } \\
\text { vessels in } \\
\text { Canadian } \\
\text { waters }\end{array}$ \\
\hline MPR, s. 320 & $\mathrm{x}$ & $x$ & & & \\
\hline $\begin{array}{l}\text { Regulation } \\
2.3 \text { of MLC } \\
2006 \text { (MPR, } \\
\text { s. } 321 \text { ) }\end{array}$ & & & $\mathrm{x}$ & $\mathrm{x}$ & $\mathrm{x}$ \\
\hline
\end{tabular}

in every 48 -h period. These standards allow seafarers to work continuously $16-18 \mathrm{~h}$ in a 24-h period. Even compared to international maritime labour standards, seafarers working on Canadian domestic water are subject to a lower standard of rest hours. Under Regulation 2.3 of the MLC 2006, minimum hours of rest shall not be less than (i) $10 \mathrm{~h}$ in any 24 -h period and (ii) $77 \mathrm{~h}$ in any 7-day period. Canada adopts the equivalent standards for ships engaged on near coastal voyages while the ship is in the water of a foreign state that has ratified the MLC 2006 for ships engaged on unlimited voyages and for foreign ships in Canadian waters (Table 10.3) (CSA 2001, ss. 319 (2), 321, 324).

On a Canadian vessel on the Great Lakes and St. Lawrence Seaway, Section 320 of the MPR is applicable to Canadian seafarers. However, on a foreign vessel, Regulation 2.3 of the MLC 2006 would be applicable. As a result, during a 14-day period, Canadian domestic seafarers would be entitled to a minimum $112 \mathrm{~h}$ of rest, which is $42 \mathrm{~h}$ less compared to international seafarers' $154 \mathrm{~h}$ of rest, even though they are working in a same region. Considering the demanding nature of navigation in Canadian waters, including the constant irregular working hours on the Great Lakes and St. Lawrence Seaway and complicated ice navigation in Arctic waters, lower labour standards for minimum hours of rest applicable to Canadian domestic seafarers may exacerbate the risk of fatigue-related incidents and accidents in Canadian waters.

The second gap between standards is marine workers' right to participate in safety management. The workplace health and safety committee is a key institution under Canadian occupational health and safety law, but mandatory establishment of a workplace health and safety committees is not applicable to ships. According to Section 135 (1) of the Canada Labour Code, "for the purposes of addressing health and safety matters that apply to individual work places, and subject to this section, every employer shall, for each work place controlled by the employer at which twenty or more employees are normally employed, establish a workplace health and safety committee and ... select and appoint its members." However, an employer is not required to establish such a committee for a workplace that is on board a ship in 
respect of employees whose base is the ship. Canadian ships are, however, required to have health and safety representatives. As per Section 136 (1) of the Code, every employer shall, for each workplace controlled by the employer that is not required to establish a workplace committee, appoint a person as the health and safety representative (Shan and Lippel 2019).

This exemption for a workplace health and safety committee makes Canadian maritime workers' right to participate in health and safety management lower compared to land-based workers. In addition, this exemption may also place Canada, as a party to the MLC 2006, not fully able to comply with its obligations to provide minimum health and safety protection standards. According to the MLC 2006 Standard A4.3.2(d), a ship's safety committee shall be established on board a ship on which there are five or more seafarers and seafarers should be appointed or elected as safety representatives to participate in meetings of the ship's safety committee. However, the current Canadian health and safety regulations allow a ship with more than 20 seafarers to operate with a safety representative, selected from the crew, rather than with a properly established health and safety committee on board. This gap in seafarers' occupational health and safety rights between the Canada Labour Code and the MLC 2006 should be filled to ensure sufficient protection of Canadian seafarers. Further, it is necessary to require a mandatory workplace health and safety committee on board a vessel with more than five seafarers and to remove the exemption provided by the Canada Labour Code in order to ensure that Canadian domestic seafarers have equivalent rights to international seafarers, as well as domestic land-based workers.

The third gap is related to the right to refuse dangerous work (Shan and Lippel 2019). As a general rule provided by Section 128(1) of the Canada Labour Code, an employee may refuse to work if he/she has reasonable cause to believe that a condition exists in the workplace that constitutes a danger to the employee or other employee, unless the refusal may put another person's life or safety in danger. On board ships, the exercise of the right to refuse dangerous work is more complicated. As per Section 128(3) of the Canada Labour Code, once a danger is identified at the workplace on a ship in operation (casting off from a wharf in a Canadian or foreign port until it is next secured alongside a wharf in Canada), the employee has a primary obligation to notify the person in charge of the ship (usually the captain), and that person should decide whether or not the employee may discontinue the work. If the person in charge commands the employee to continue their work, then the employee shall not discontinue the work. The extra conditions for seafarers to exercise their rights may restrict their capability of self-protection and expose them to greater risks (Shan and Lippel 2019).

Although there are certain gaps in the Canadian maritime occupational health and safety legal system, Canada does have a communication platform, the Canadian Marine Advisory Council. With representatives from industry, labour and government, the Council enables the government to keep improving Canadian maritime OHS standards together with the industry, trade unions and other non-governmental organizations (Transport Canada 2019). 


\subsection{Conclusion}

The high risk of a fatal accident in the maritime sector indicates that additional regulatory efforts are required to ensure the health and safety of workers at sea. In addition, considering the expansion of Arctic maritime activities due to climate change, intensive work-related mobility in Canada, and the existing gaps in occupational health and safety protection standards between Canadian domestic seafarers, international seafarers and land-based workers, how to protect Canadian seafarers is an important question to address.

This chapter, based on findings from empirical studies and legal analysis, sets out some of the health and safety challenges facing Canadian seafarers. In the current literature on seafarers' health and safety issues, major attention has been paid to international deep-sea seafarers, while domestic short-sea seafarers are underexamined. However, with the opening of the Arctic, as well as increasing international regulatory efforts to ensure decent working conditions at sea, the necessity to examine the health and safety challenges faced by Canadian seafarers, particularly in the Arctic, is becoming prominent. Maritime occupational health and safety challenges are not restricted to hazards related to the environment at sea; technical challenges and labour process on board, commuting and high-level work-related mobility, limited rights and insufficient legal protection are also significant challenges, making seafarers more vulnerable.

Canada has a relatively comprehensive occupational health and safety legal framework for seafarers, which is a good start to ensure health and safety protection, although there are still some gaps to be bridged to ensure sufficient legal protection for domestic seafarers. The Canada Labour Code, Maritime Occupational Health and Safety Regulations, Canada Shipping Act, 2001, and Marine Personnel Regulations are the primary legal instruments that provide protection for seafarers. The Canadian Marine Advisory Council also provides a communication platform between the industry, labour and government. The OHS challenges facing seafarers can be addressed with more concerted efforts from government, industry and labour organizations. To ensure Canadian seafarers can access sufficient legal rights to participate in health and safety is important for the healthy development of Canadian shipping, as well as the ocean economy.

Acknowledgement This research was funded by the Ocean Frontier Institute International Postdoctoral Fellowship, On the Move Partnership, Canada and the Canada Research Chair in Occupational Health and Safety Law (Grant No. 950-228353), funded by the Social Sciences and Humanities Research Council of Canada. The On the Move Partnership: Employment-Related Geographical Mobility in the Canadian Context is a project of the SafetyNet Centre for Occupational Health \& Safety Research at Memorial University. On the Move is supported by the Social Sciences and Humanities Research Council of Canada through its Partnership Grants funding opportunity (Application ID 895-2011-1019), Innovate NL, Government of Newfoundland and Labrador, the Canada Foundation for Innovation and numerous university and community partners in Canada and elsewhere. 


\section{References}

Borovnik, M. (2004). Are seafarers migrants? Situating seafarers in the framework of mobility and transnationalism. New Zealand Geography, 60(1), 36-43.

Canada Labour Code, RSC 1985, c L-2.

Canada Shipping Act, 2001, SC 2001, c 26.

CCA (Council of Canadian Academies). (2017). The value of commercial marine shipping to Canada. Ottawa: CCA

CCA (Council of Canadian Academies). (2016). Commercial marine shipping accidents: Understanding the risks in Canada. Ottawa: CCA.

Coasting Trade Act, SC 1992, c 31 (Canada).

East Coast and Great Lakes Shipping Employees Hours of Work Regulations, 1985, CRC, c 987 (Canada).

Eguíluz, V. M., Fernández-Gracia, J., Irigoien, X., \& Duarte, C. M. (2016). A quantitative assessment of Arctic shipping in 2010-2014. Scientific Reports, 6, 30682. https://doi. org/10.1038/srep30682.

Hansen, H., Nielsen, D., \& Frydenberg, M. (2002). Occupational accidents aboard merchant ships. Occupational Environmental Medicine, 59(2), 85-91.

International Labour Organization. (2018). Direct Request (CEACR): adopted 2017, published 107th ILC session (2018): Maritime Labour Convention, 2006 (MLC, 2006): Canada (Ratification: 2010). https://www.ilo.org/dyn/normlex/en/f?p=1000:13100:0::NO:1310 0:P13100_COMMENT_ID:3341742:NO. Accessed 10 Nov 2019.

Jensen, O. C., Sørensen, J. F., Kaerlev, L., Canals, M. L., Nikolic, N., \& Saarni, H. (2004). Selfreported injuries among seafarers: Questionnaire validity and results from an international study. Accident Analysis \& Prevention, 36(3), 405-413.

Larson, D. 1997. Working by the bells: Life aboard the Courtney Burton, a Great Lakes carrier. Lake Superior Magazine. https://www.lakesuperior.com/the-lake/maritime/working-by-thebells-life-aboard-a-great-lakes-carrier/. Accessed 10 Nov 2019.

Lasserre, F. (2019). Arctic shipping: A contrasted expansion of a largely destinational market. In M. Finger \& L. Heininen (Eds.), The global Arctic handbook (pp. 83-100). Cham: Springer.

Lasserre, F., \& Faury, O. (Eds.). (2020). Arctic shipping: Climate change, commercial traffic and port development. London: Routledge.

Lefkowitz, R. (2013). Incidence of injury and illness in merchant seafarers. Master of Public Health thesis, Yale University.

Lippel, K., Eakin, J. M., Holness, D. L., \& Howse, D. (2016). The structure and process of workers' compensation systems and the role of doctors: A comparison of Ontario and Québec. American Journal of Industrial Medicine, 59(12), 1070-1086.

Mäkinen, T. M., \& Hassi, J. (2009). Health problems in cold work. Industrial Health, 47(3), 207-220.

Marine Personnel Regulations, SOR/2007-115 (Canada).

Maritime Occupational Health and Safety Regulations, SOR/2010-120 (Canada).

Minister of Transport. (2015). Pathways: Connecting Canada's transportation system to the world. Ottawa, ON.

MLC. (2006). Maritime Labour Convention, 2006 (23 February 2006, entered into force 20 August 2013), 45 ILM 792 (2006).

Pauksztat, B. (2017). "Only work and sleep": Seafarers' perceptions of job demands of short sea cargo shipping lines and their effects on work and life on board. Maritime Policy \& Management, 44(7), 899-915.

Pienimäki, T. (2002). Cold exposure and musculoskeletal disorders and diseases: A review. International Journal of Circumpolar Health, 61(2), 173-182.

Polar Code. (2014/2015). International Code for Ships Operating in Polar Waters (Polar Code), IMO Resolution MSC.385(94) (21 November 2014, effective 1 January 2017); Amendments to the International Convention for the Safety of Life at Sea 1974, IMO Resolution MSC.386(94) 
(21 November 2014, effective 1 January 2017); Amendments to MARPOL Annexes I, II, IV and V, IMO Resolution MEPC.265(68) (15 May 2015, effective 1 January 2017). http://www. imo.org/en/MediaCentre/HotTopics/polar/Documents/POLAR\%20CODE\%20TEXT\%20 AS\%20ADOPTED.pdf. Accessed 17 Oct 2019.

Rezaee, S., Pelot, R., \& Finnis, J. (2016). The effect of extratropical cyclone weather conditions on fishing vessel incidents' severity level in Atlantic Canada. Safety Science, 85, 33-40.

Roberts, S. E., Nielsen, D., Kotłowski, A., \& Jaremin, B. (2014). Fatal accidents and injuries among merchant seafarers worldwide. Occupational Medicine (London), 64(4), 259-266.

Roussel, D. (2018). Opportunities and potential impact of autonomous vessels: How should Canada position itself? Paper presented at the Transport Canada Workshop on Maritime Autonomous Surface Ships, Ottawa.

Sampson, H. (2013). International seafarers and transnationalism in the twenty-first century. Manchester: Manchester University Press.

Sampson, H., Ellis, N., Acejo, I., \& Turgo, N. (2017). Changes in seafarers' health 2011-2016: A summary report. Cardiff: Seafarers International Research Centre.

Shan, D., \& Lippel, K. (2019). Occupational health and safety challenges arising from employmentrelated geographical mobility (E-RGM) among Canadian seafarers on the Great Lakes and St. Lawrence Seaway. New Solutions: A Journal of Environmental and Occupational Health Policy, 29(3), 371-396.

Shan, D., \& Neis, B. (2019). Employment-related mobility and fatigue on the Great Lakes and St. Lawrence Seaway: Canadian seafarers' experiences. Safety Science, 121, 165-176.

Sillitoe, A., Upcraft, D., Rich, K., LaRoche, M., Røed, B., \& Huse, J. (2010). Supporting human performance in ice and cold conditions. London: Lloyd's Register.

Silverman, D. (2011). Interpreting qualitative data: A guide to the principles of qualitative research. London: SAGE.

Statistics Canada. (2012). Shipping in Canada 2011. Ottawa: Statistics Canada.

Statistics Canada. (2015). Canadian international merchandise trade database. https://www150. statcan.gc.ca/n1/en/catalogue/65F0013X. Accessed 10 Nov 2019.

Statistics Canada. (2016). International perspective. https://www150.statcan.gc.ca/n1/ pub/11-402-x/2012000/chap/geo/geo01-eng.htm. Accessed 10 Nov 2019.

The St. Lawrence Seaway Management Corporation. (2019). Joint practices and procedures respecting the transit of ships on the St. Lawrence Seaway. http://www.greatlakes-seaway. com/seaway_handbook/seaway-handbook-en/practices_and_procedures.pdf. Accessed 10 Nov 2019.

Transport Canada. (2015). Transportation in Canada 2014. Ottawa: Transport Canada.

Transport Canada. (2019). Engagement opportunity: Marine safety and security regulations. https://www.tc.gc.ca/eng/engagement-marine-safety-security-regulations.html. Accessed 10 Nov 2019.

UNCTAD (United Nations Conference on Trade and Development). (2019). Review of maritime transport 2018. New York/Geneva: United Nations.

Walters, D., \& Bailey, N. (2013). Lives in peril: Profit or safety in the global maritime industry? Basingstoke: Palgrave Macmillan.

West Coast Shipping Employees Hours of Work Regulations, CRC, c 992 (Canada).

WorkSafe BC. (2019). Injury rate (2009 to 2017). https://public.tableau.com/profile/worksafebc\#!/ vizhome/Provincialoverview/Didyouknow. Accessed 10 Nov 2019. 
Open Access This chapter is licensed under the terms of the Creative Commons Attribution 4.0 International License (http://creativecommons.org/licenses/by/4.0/), which permits use, sharing, adaptation, distribution and reproduction in any medium or format, as long as you give appropriate credit to the original author(s) and the source, provide a link to the Creative Commons license and indicate if changes were made.

The images or other third party material in this chapter are included in the chapter's Creative Commons license, unless indicated otherwise in a credit line to the material. If material is not included in the chapter's Creative Commons license and your intended use is not permitted by statutory regulation or exceeds the permitted use, you will need to obtain permission directly from the copyright holder. 